\title{
Study on Curriculum Reform of Shaanxi Higher Education
}

\author{
Hui-jie Yang \\ School of Xi' an peihua University \\ Xi' an, China
}

\begin{abstract}
Shaanxi higher education is third in the country; The quality of development directly affects the quality of China's higher education. China is in a period of rapid development, and the demand for high-quality talents is quite large. How to cultivate talents to meet the needs of the society has become a problem that universities should think about today. This study draws lessons from the United States. The advanced experience of MIT, with the undergraduate course system as the research object, is based on the curriculum reform of higher education institutions in China. The structure, types and characteristics of MIT's undergraduate curriculum are emphatically analyzed, and measures are proposed to solve the problems encountered in the curriculum reform of Chinese universities. In order to push forward the reform of higher education in China and deepen the optimization of university curriculum system, new ideas are provided for the innovation of university curriculum reform model and action.
\end{abstract}

Keywords-higher education; undergraduate course setting; course features

\section{THE NECESSITY AND RATIONALITY OF CURRICULUM SETTING}

With the increase of society's attention to higher education, the importance of the course has been paid more and more attention. The curriculum is the basic basis of education teaching activities, the basic guarantee to achieve the education goal of the school, the intermediary of all teaching activities of the school, and the standard for school management and evaluation. Courses are directly related to students' personal development. Excellent curriculum setting provides a good way for students to develop their ability and improve their quality, and even helps students to make correct plans for their life. The greater value of the course is that it is a bridge between universities and social progress and technological development. Therefore, the study of curriculum has always been the direction of the majority of scholars, as well as a necessary link of university development and reform.

This paper belongs to the research paper on the scientific planning of education in Shaanxi province in 2017, the project name: the adjustment of the industrial supply side structure to the reform of the curriculum setting in Shaanxi colleges and universities. Project No.:SGH17h452.

\section{THE SETTING OF HIGHER EDUCATION UNDERGRADUATE COLLEGES IN CHINA IS NOT REASONABLE, WHICH LEADS TO THE UNREASONABLE COURSE SETTING}

A. China's Colleges and Universities Have TooMany Internal Branches, Which Are Not Conducive to the Cultivation of Comprehensive Talents

Take MIT; MIT has six divisions with 31 departments and majors. However, domestic institutions such as xi 'an The traffic university have 29 branches, and I have listed 23 branches.

By comparing the college setting of MIT and xi 'an The traffic university, it can be seen that the college setting of MIT in the United States is based on the discipline class and emphasizes comprehensiveness. And our country is with the industry standard, cent is too detailed; This is not conducive to the cultivation of comprehensive talents, is not conducive to innovative thinking.

\section{B. The MIT Curriculum Is Designed to Be Innovative and Open}

Take electrical engineering and computer science as examples. Nearly 25 percent of MIT's undergraduate students are majoring in electrical engineering and computer science.

By analyzing the curriculum and curriculum of electrical engineering and computer science majors at MIT, it is not difficult to find that the curriculum setting of the majors at MIT is characterized by universality, stage and autonomy. In the article "evolution and practice of MIT education concept", he Zhenhai and guo junchao summarized the different education concepts of MIT in three different historical periods in detail. [1] cheng guangxu's article "the characteristics of running MIT in the United States and its enlightenment" summarizes the characteristics of running MIT. [2]

\section{1) Foundation course}

a) General education

b) Elective courses

2) Extended course

The expansion course focuses on expanding students' thinking and ability and broadening their knowledge horizon. Typical extension courses include: 


\section{a) Collection items}

b) Independent activity period refers to the period when teachers and students conduct relatively independent and flexible learning and research activities outside the normal curriculum arrangement. Usually in January for four weeks. But many of the independence activities were planned as early as November of the previous year.

\section{c) Undergraduate internship program}

3) Research curriculum

The research courses focus on cultivating students' attitude and ability of inquiry. This kind of course often exercises hands-on ability, research spirit and innovation consciousness through students' own exploration and research, and pays more attention to the research process than the research conclusion. Research courses at MIT include:

a) Experimental research group

The experimental research group is an innovative academic program for freshmen who have an active interest in college life.

\section{b) Laboratory courses}

$\mathrm{Xu}$ Qinghua, in the article "the agreement on the right of interests between the media lab and corporate sponsors of MIT", starting from the history of cooperation between American universities and enterprises, analyzed the formation of the agreement on the right of interests between media lab and corporate sponsors, pointed out the potential conflict of cooperation, and proposed the way of establishing perfect information communication channels. [3]

\section{c) Undergraduate research opportunities program}

It is considered to be one of the earliest and most successful undergraduate research programs in the United States. The program is an intellectual collaboration between research-based undergraduates and teachers Plan [4].

\section{THE ENLIGHTENMENT TO CHINA'S HIGHER EDUCATION CURRICULUM REFORM}

\section{A. General Education Concept Guide}

General education is the stage of higher education for the students to implement the comprehensive quality of a kind of occupational and professional education, aims at providing students with comprehensive balance system of education, cultivate students' scientific and cultural knowledge and basic skills, improve students in moral, cultural and artistic accomplishment, pay attention to cultivate students' ability of self-education and lifelong education.

\section{B. Diversified Value Orientation of Curriculum}

The curriculum of MIT embodies the value orientation of diversity, which is the integration of the three value orientations of human, Wang Shuowang, hong chengwen in (CDIO: engineering at the Massachusetts institute of technology education of classical model, based on the interpretation of CDIO syllabus ", through the course outline) target system of the curriculum goal, content and adjust the use of in-depth analysis, and put forward the training mode innovation of our country several enlightenment [5].

\section{Innovative Personnel Training Mode}

MIT's engineering school aims to "train students to be leaders in industry, government and education, influencing the future direction of education and industry". This requires students to be innovative, not just ordinary industrial workers [6].

\section{HOW DO WE DO IT}

\section{A. The General Education Course and the Specialized Curriculum Unifies, Raises the Comprehensive Development Person}

Our institutions of higher learning should strive to create an academic atmosphere in which various disciplines such as literature, science and engineering interact with each other, broaden the range of students' knowledge and achieve an effective combination of humanities and science and technology. Under the guidance of this education concept, students, whether majoring in liberal arts or science and engineering, can receive relatively comprehensive and balanced basic learning to form a comprehensive knowledge system and achieve lifelong self-education.

\section{B. Combine Theoretical Courses with Practical Courses to Cultivate People with Professional Skills}

Starting from the professional basic courses, we set up experimental courses for students to demonstrate the theories we have learned through practical operation. Besides, we also divided the experimental courses into compulsory courses, and stipulated the required number of courses and academic scores, so as to cultivate students' practical ability and rigorous and practical style of study.

\section{Combine Required Courses with Elective Courses to Cultivate people with Personality}

Students can choose their major after enrollment. Generally at the end of the first school year initial choice, the second school year before the final decision, period can be adjusted. The school arranges a tutor for each student to help them design study programs, select courses and major. Students can also apply for double degrees or minor majors. This system of course selection and major selection provides students with opportunities to fully understand their own interests and hobbies and develop them into specialties. Students who have grown up through this training mode not only have systematic professional knowledge and skills, but also stand out as people with distinctive personality and development potential.

\section{ACKNOWLEDGMENT}

This paper belongs to the research paper on the scientific planning of education in Shaanxi province in 2017, the project name: the adjustment of the industrial supply side structure to the reform of the curriculum setting in Shaanxi colleges and universities. Project No. : SGH17h452. 


\section{REFERENCES}

[1] Zhenhai, guo junchao. Evolution and practice of MIT education concept [J]. Journal of xingtai polytechnic college, 2005, (4). .(In Chinese).

[2] Cheng guangxu. The characteristics of NIT in the United States and their implications [J]. Journal of xi 'an jiaotong university (social science edition), 2002, (1) .(In Chinese).

[3] Xu qinghua. Interest agreement between MIT media lab and corporate sponsors [J]. Management scholar (academic edition), 2009, (3) .(In Chinese).
[4] Li lianming. Summary of research on academic management of MIT [J]. Higher sciences education, 2002, (6)..(In Chinese).

[5] Gong yu, Chen min, A comparison of the undergraduate curriculum setting of education in Chinese and American higher engineering -- a case study of Shanghai jiaotong university and Massachusetts institute of technology [J]. University (research and evaluation), 2009, (6) .(In Chinese).

[6] Zhao hong. The comparative analysis of Chinese and American economics course education takes MIT (MZT) and huazhong university of science and technology as examples [J]. Higher education exploration, 2005, (4).(In Chinese). 